\title{
Reflections on Improving Business English Teaching through Web - based Courses
}

\author{
Lu Sun \\ Harbin University of Commerce, Harbin, China, 150028 \\ SUN_LU1980@163.com
}

Keywords: Network course; business English; Web - based Courses

\begin{abstract}
The emergence and development of business English is the necessity of the times. It is the need of business English teaching object, learning subject, teaching goal and teaching method. Business English teaching and learning have its own uniqueness. This uniqueness decision The Necessity and Importance of the Construction of Business English Network Course. Only in the scientific analysis of these unique characteristics, based on the operation of business English teaching their own rules, in order to build a good, the implementation of good business English network courses.
\end{abstract}

\section{Introduction}

The need of business English network course construction is rooted in the social background, teaching object, learning subject, teaching goal and teaching method of business English teaching. Therefore, it is inseparable from the construction of business English course On the above aspects of systematic qualitative investigation and analysis. At the same time, this kind of investigation and analysis has become the realistic basis and theoretical foundation of the construction of business English network course. With the development of China's socialist market economy and the increasingly frequent international economic exchanges, the society needs more and more both understand English and understand the high-quality talents of business. As a result, to cultivate complex foreign business talents for business purposes for the business English professional came into being. This is fully reflected in the new syllabus of English major in higher education (hereinafter referred to as the new syllabus). For example, in the new syllabus, "Several Opinions on Foreign Language Majors' Reform of Undergraduate Education in the 21st Century" (hereinafter referred to as " Opinions ") pointed out that foreign language proficiency is currently being tested" foreign language + professional knowledge "," foreign language + professional direction "and so on. Business English is one of the experimental models described in the new syllabus.

\section{The Business English Teaching Object Analysis}

Business English teaching object analysis refers to the business English teaching syllabus, curriculum, teaching materials, learning content analysis. In the business English syllabus and curriculum, the new "outline" only at the macro level put forward the general business English teaching guiding ideology, and encourage colleges and universities according to their own advantages to develop distinctive business English teaching syllabus. However, in reality, the syllabus of colleges and universities has the shortcomings of one way or another, which is very unfavorable to the improvement and development of the comprehensive quality of business English majors. First of all, colleges and universities should be their own business English professional teaching status, such as teachers, teaching resources, etc. have a clear understanding and objective assessment. Then, according to the understanding and assessment, to develop in line with the region's economic development, the actual school, students learning the syllabus. In the process of development, we should follow the principle of highlighting the professionalism and highlighting the sustainable development. This is the decisive factor in the development of professional learning and professional competence. It is the core of cultivating qualified business English talents. On the other hand, in the diversity of curriculum, we should overcome the shortcomings of the traditional 
English language communication, business English conversation and other courses, and vigorously develop business English intensive reading, especially business English newspaper reading, business English negotiation, translation ( Interpreting and translating), listening and other professional courses, as well as import and export business (English version), Anglo-American business culture and international economic law and other professional elective courses. Therefore, the construction of business English network course is the inevitable requirement of business English teaching syllabus.

\section{Business English Learning Subject Analysis}

Business English learning subject analysis is the analysis of business English majors (or "business English learners"). The applicability of business English specialty, the characteristics of compound and the nature of the professional learning content determine the particularity of business English majors. Business English majors are the main body of teaching activities, which is the most active and the most influential factor in teaching. The observation and analysis of this subject is an important basis for the construction of business English course. In general, business English majors are significantly different from those of other foreign language professions (such as English language and literature, science and technology, legal English or Japanese majors) in terms of professional learning, socialization and development. In particular, the family background, learning psychology and learning process of business English majors are more complicated. The learning focus has changed regularly in the course of learning, and the learning mode and learning methods show diversity. Secondly, the internal and external environment of the socialization of business English majors is also very different from that of other foreign language majors. In the process of transforming students from foreigners to foreign businessmen, the professional and teaching methods of the course are different from their individuality, way of thinking and behavior Have a different degree of impact; again, the future of the business environment and career determines the business English professional students development direction and development model. Obviously, the business English network course builder must consciously examine the complexity of the learners, learn the change of the key stage and the diversity of the learning methods, and put this investigation into every part of the network course construction, Open, free and professional learning platform, and as a basis to guide and standardize student learning behavior, so that they effectively improve their professional skills, the smooth realization of the role of conversion for its future sustainable development pave the way.

\section{Business English Teaching Objectives Analysis}

From the above discussion, we can see that the goal of business English teaching is to train high-quality, compound, and application-oriented foreign business English talents. Specifically, we can break this overall goal into three levels: one is the level of knowledge, the second is the level of competence, the third is cross-cultural business English communication quality. For these three levels, we should from the following three latitude to analyze and solve the business English teaching and learning problems: First, the language latitude, that is, English teaching and learning, the second is the professional business latitude, that is, business teaching and learning, Third, business English as a special purpose English (ESP) latitude, that is, the real sense of business English teaching and learning. In fact, it is not easy to start from these three latitudes to achieve the above three levels of goals. How to integrate the business English teaching resources is not enough to solve this problem, to achieve business English professional teaching objectives of the key. But how to integrate the existing teaching resources to rely on the traditional teaching mode and teaching organization is clearly not enough, on the contrary, the use of modern educational technology, multimedia network course is a good choice. On the other hand, the quality of cross-cultural business communication is located at the highest level of the overall goal of business English teaching. This goal includes at least three levels: one is pragmatic ability, two is business operation ability, three is cross-cultural communication consciousness and communicative 
competence The Therefore, any course designed to improve the learner's ability to cross-cultural business communication must do the following three points: First, you must provide enough authentic business English teaching materials and teaching activities to exercise learners' pragmatic competence ; Second, the teaching materials must have a strong business professional, must be closely linked to the actual business operations; Third, we must provide a wealth of cultural information, a variety of cultural styles, to cultivate learners cross-cultural communication awareness and communication skills The Obviously, it is not easy to achieve these terms at the same time, but the Business English course is able to meet the above requirements to the greatest extent possible. To sum up, the business English network course construction can integrate the business English teaching resources to the greatest extent, cultivate the learners' awareness and ability of intercultural business communication, and finally realize the overall goal of business English teaching.

\section{The Analysis of Business English Teaching Methods}

In the business English teaching mode and method, according to the new "outline" spirit, compound business English talent training should follow the overall business English teaching model. From this basic point of view, according to the characteristics of business English and the psychological characteristics of students, we should adopt the constructivist teaching mode and the two-way coupling training mode of business and English interaction in business English knowledge teaching. In the ability teaching, Oriented teaching model; in the overall quality of teaching, should adopt the cultural teaching mode. Among them, in the process of implementing the constructivist teaching mode, we should pay attention to the connection and difference between different "knowledge blocks", and set up a "bridge" to the reasonable knowledge structure between "known" and "unknown" In the "warm and know the new" on the basis of "external" knowledge "internalization" as part of their own quality. The coupling mode of business and English interaction is the coupling of business characteristics and English language characteristics, coupling of business knowledge structure and English knowledge structure to form and improve the pragmatic competence of business English. A competency-oriented teaching model means that all teaching activities and knowledge learning must be guided by capacity formation, development and improvement. In the teaching method, business English teaching must fully consider the business English teaching object and learning the uniqueness of the subject. From the perspective of modern pedagogy, business English teaching is very suitable for the use of task teaching method. Communicative teaching method requires convenient and equal teacher and student two-way communication; case teaching method requires the selected teaching materials to keep the pulse of the times, and conducive to the creation of realistic teaching scene; and the task of teaching law requires knowledge to teach the rational, structural and system Sex. Obviously, the above-mentioned business English teaching model and teaching methods of the unique and related requirements of non-multimedia network courses can not be fully realized. Therefore, we can say that business English network course construction is also a business English teaching model and teaching methods of the inevitable requirement.

\section{Conclusions}

The emergence and development of business English is the necessity of the times. Business English teaching and learning have their own uniqueness. This uniqueness determines the necessity and importance of the construction of business English course. We only in the scientific analysis of these unique, based on the business English teaching their own laws of operation as a guide in order to build a real sense, and ultimately the implementation of business English network courses. 


\section{Acknowledgements}

This paper is supported by Philosophy and Social Scientific Research Project Foundation of Heilongjiang Province (No.14C009).

\section{References}

[1] Wei Chuanli, Practice and theoretical basis of public management research in China, China Electronic Commerce .2012. (10)

[2] Wei Chuanli, On the Problems in the Study of Public Administration in China, China's Foreign Trade .2012 (8)

[3]Sun Lu, Study on Self-learning of Business English Students by Network, MEICI2015, 2015.10 [4]Sun Lu, The Practice of Business English Cooperative Learning in the Network Environment, ICEMC2016,2016.05

[5] Sun Lu, raining of Foreign Trade-Oriented Business English Major, ICEMC2016,2016.05

[6]Sun Lu, On Using Podcasting to Teach in Mobile Foreign Language Learning, EMCM2016,2016.12

[7]Sun Lu, Discussion on the Reform of Foreign Language Teaching in College, EMCM2016,2016.12

[8] Sun Lu, Discussion on the Training Mode of Business English Major, EMCS2017.05

[9] Sun Lu, Study on Business English Teaching, EMCS2017.05

[10] Wei Chuanli, SME technical efficiency and scale revenue calculation methods and selection of indicators, Computer modeling and new technologies, 2014.12 